\title{
'n Nuwere benadering tot "gattungsforschung"
}

\author{
A G VAN AARDE
}

\section{Vooraf opmerkings}

1 Gattungsforschung word in resente literatuur ook met die terme Gattungskritik of Gattungsgeschichte aangedui. Dit is 'n term wat tradisioneel identies met die term Formgeschichte (of die Engelse Form Criticism) gebruik is, of die een as 'n oorkoepelende begrip ten opsigte van die ander. My voorkeur om die term Gattungsforschung te kies as aanduiding vir die metode van ondersoek na literêre tipes in Bybelse literatuur sal hopelik aan die einde van die artikel vanself spreek.

2 Formgeschichte is ' $\mathrm{n}$ element in die histories-kritiese model van eksegese en het sy ontstaan te danke aan die eensydigheid van die ou literarkritische metode soos dit veral deur die Julius Wellhausenskool beoefen is. Sedert die einde van die Tweede Wêreldoorlog het die formgeschichtliche metode verrassend vinnig 'n baie prominente plek onder die ondersoekmetodes van Bybelse literatuur ingeneem. Weliswaar só dat daar van die standpunt uitgegaan is dat ' $n$ Bybelse skrifgedeelte eers dan reg geïnterpreteer kan word wanneer'n studie van sy spesifieke literêre vorm en sy besondere Sitz im Leben gedoen is. Hermann Gunkel, in vele opsigte die vader van hierdie ondersoekmetode, se uitspraak in hierdie verband is wêreldwyd bekend: "Wer einen Schriftsteller untersucht, ohne die von ihm gebrauchte Gattung zu kennen, beginnt den Bau des Hauses mit dem Dach". ${ }^{1}$

3 Vir ' $n$ tyd lank het die Bybelse literatuurwetenskap nie van die resultate van die nuwere ontwikkeling op die gebied van die algemene linguistiek met sy sleutelwoord "struktuur" kennis geneem nie. Die situasie het vandag egter ietwat verander. Wat Gattungsforschung betref, is dit veral die Duitse Ou-Testamentikus Wolfgang Richter $^{2}$ wat op grond van die nuwere insigte, met 'n ander bril na die tradisionele formgeschichtliche ondersoekmetode begin kyk het. Richter se eksegetiese benaderingswyse staan bekend as die sogenaamde "metodepluralie". Dit is 'n eksegetiese benadering waarin verskeie metodiese fasette almal hulle goeie reg en noodsaak het, soos Literarkritik, tekskritiek, struktuur, Gattung, semantiek, historiese perspektiewe soos tradisiekritiek en laastens redaksiekritiek. Sy literatuurteorie (waarby sy nuwere benadering tot Gattungsforschung inbegrepe is) kom in hoofsaak neer op 'n poging om 'n raffinering van die bestaande literêre ondersoekmetodes te bied, en 'n 
poging om met die oog op die vasstelling van betekenis, die diachroniese met die sinchroniese fasette te paar. Die volgorde is egter altyd dat die sinchroniese die materiaal bied waarop die diachroniese gebou moet word, en nie andersom nie. Hierdie uitgangspunt het spoedig ' $n$ veranderde situasie in die metodologiese besinning gebring. Dit is veral opmerklik in die boek Exegese des Alten Testaments. Einführung in die Methodik wat in 1973 onder redaksie van Georg Fohrer en ander medewerkers uitgegee is. Gunther Wanke skryf in hierdie boek byvoorbeeld soos volg: "Die sprachliche Analyse bildet ferner die Grundlage für alle weiteren exegetischen Schritte, vor allem für die Formen- und Gattungskritik und die Motiv-und Traditionskritik, wobei sich beide in ihrer Frage nach geprägtem Gut auf die Ergebnisse der sprachlichen Analyse stützen". ${ }^{3}$ Hier te lande is J A Loader' $n$ eksponent van hierdie benadering van eksegese van $\mathrm{Ou}-$ Testamentiese tekste." Wat die Nuwe Testament betref, is die "multilinearen Betrachtungsweise" van Klaus Berger ${ }^{5}$ bekend, hoewel glad nie in ooreenstemming met dié van Richter nie, en myns insiens ook onaanvaarbaar (sien later). Vir kritiek op Richter kan veral die werke van Klaus Koch ${ }^{6}$ en $\mathrm{H}$ Barth en O H Steck ${ }^{7}$ vermeld word.

Wat vir Richter se motief ten opsigte van sy benaderingswyse in die geheel geld, geld ook vir 'n afsonderlike faset daarvan soos Gattungsforschung: Hy wil naamlik deur middel van kontroleerbare kriteria grense stel aan die vertroue van die kritikus op gevoel, fantasie en intuïsie $e^{8}$ - iets waarop die tradisionele benadering nie eintlik kan roem nie. Richter het nie alleen die reeds bekende feit beklemtoon dat daar in die tradisionele formgeschichtliche benadering verskillende rigtings bestaan nie, maar hy is ook van mening dat daar sedert Gunkel nog nooit genoegsaam erns gemaak is met die kriteria van hierdie ondersoekmetode nie. ${ }^{9}$ Dit geld nie alleen ten opsigte van die Ou Testament nie, maar ook ten opsigte van die Nuwe Testament.

4 Hierdie artikel beoog om op die voetspoor van Richter - egter nie sonder kritiek en metodologiese wysigings nie, op grond van die gesag van die insigte van die nuwere taal- en literatuurwetenskap, die leemtes in die tradisionele Formgeschichte verder uit te wys. Op grond van hierdie insigte word 'n nuwere benadering tot Gattungsforschung bespreek en verfyn. Dit is veral drie belangrike insigte wat in hierdie.verband ter sake is en wat al drie te danke is aan die baanbreker van die moderne linguistiek, Ferdinand de Saussure. ${ }^{10}$ Hierdie drie insigte is die onderskeid tussen la langue en la parole, tweedens die strukturele metode van taalstudie en derdens die onderskeid tussen sinchronie en diachronie.

5 Gattungsforschung het binne die ondersoek van die Ou Testament nie dieselfde oogmerke as dié binne die Nuwe Testament nie, hoe- 
wel dit by beide literatuurkorpusse dieselfde vader het. Dit is my oortuiging dat die resultate van Richter se ondersoek ten opsigte van die Ou Testament ook met vrug ten opsigte van die Nuwe Testament toegepas kan word, al het geen navorser, sover my kennis strek, dit nog gedoen nie.

Die uiteensetting wat nou volg, word gedoen by wyse van ' $n$ viertal opskrifte, te wete "Die identifisering van die Gattung", "Die Sitz im Leben van die Gattung", "Die Funksie van die Gattung" en "Gattungsgeschichte".

\section{Die identifisering van die "Gattung"}

Richter bevraagteken die tradisionele benadering om die aspek van Geschichtlichkeit as kriterium te gebruik om Gattungen te identifiseer, en daarom neem hy ook nie genoeë met die term Formgeschichte nie. Hy reken dat die swakheid van die tradisionele benadering juis deur die samestelling van die term Formgeschichte weerspieël word. ${ }^{11}$ Die aspek van Geschichtlichkeit bly in die lig van die onderskeid tussen sinchronie en diachronie ' $n$ faset van Gattungsforschung met sy eie bepaalde metodiese plek. Hy wil onderskeid maak tussen wat hy noem Formenkritik en Formkritik. Beide hierdie fasette vat hy saam onder die term Gattungskritik. Gattungsgeschichte is die laaste en 'n afsonderlike faset. Hierdie onderskeid sal hopelik by die bespreking wat volg, duideliker word.

Met behulp van die literarkritische metodiese faset word perikope en tekseenhede geïsoleer. Só 'n perikoop vertoon ' $n$ "ornamentele", 'n "uiterlike" en 'n "innerlike" vorm. Die "ornamentele" is die formele gegewens in die perikoop wat verwerk word deur analise van rym, alliterasie, assonansie, ritme ensovoorts. ${ }^{12}$ Die "uiterlike" is die genoemde literarkritische afgrensing, en dit word gedoen aan die hand van kriteria soos lekseemvoorkomste, lekseemgroepe, sinsoorte en stilistiese detail. Dit sluit ook kriteria in soos herhalinge en spanninge. ${ }^{13}$ Die bepaling van die "uiterlike" vorm word gekontroleer deur die analise van die "innerlike" vorm. Laasgenoemde is die struktuur van die perikoop, en die analise hiervan word gedoen aan die hand van formele sintaktiese kategorieë. Hierdie gestruktureerde eenheid is wat Richter met die term Form aandui, en waarna ek voortaan met die term vorm of struktuur verwys.

Richter verstaan met ander woorde onder die term Literarkritik iets anders as die tradisionele "bronne-kritiek" soos dit veral deur die Wellhausen-skool toegepas is. Dit is ' $n$ term wat in Duitsland egter ook gebruik word as die omvattende aanduiding van literêre arbeid. ${ }^{14}$ Die strukturale benaderingswyse van die sogenaamde Amerikaanse "literary criticism" gebruik op sy beurt die term weer baie enger. ${ }^{15}$ Ek verkies om van perikoopafgrensing te praat as aanduiding 
van die analise van die sogenaamde "uiterlike vorm". Die perikoopafgrensing is binne die Gattungsforschung in wese niks anders nie as 'n voorlopige arbeid met betrekking tot die analise van die "innerlike vorm". Laasgenoemde noem ek struktuuranalise. Die tegniek wat ek hiervoor aanwend, is dié wat binne die raamwerk van die NuweTestamentiese Werkgemeenskap van Suid-Afrika onder leiding van J $P$ Louw ontwerp is. ${ }^{16}$ Die analise van die sogenaamde "ornamentele vorm" reken ek, anders as Richter, nie as 'n afsonderlike metodiese stap binne die Gattungsforschung nie. Die aspekte wat Richter onder hierdie term saamvat, is wel baie belangrik, maar myns insiens deel van die struktuuranalise. ${ }^{17}$

Die afgebakende tekseenhede noem Richter en Markert Formen. ${ }^{18}$ Die vergelyking van die verskillende Formen met mekaar staan by hulle bekend as Formenkritik in onderskeid met die term Formkritik. Laasgenoemde is die ondersoek na die "ornamentele", die "uiterli-

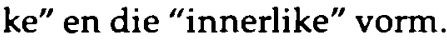

Die struktuur van elke tekseenheid is uniek. Maar wanneer verskeie sulke tekste met mekaar bepaalde ooreenkomste toon, kan sulke verwante tekste saam tot 'n tipiese groep gereken word, en só ' $n$ tipiese groep word dan saamgevat onder die term Gattung. ${ }^{19}$ Wanneer die vorm van 'n eenheid vasgestel is, dan is dit nie sonder meer duidelik of hierdie vorm eenmalig en toevallig so gestruktureer is, of 'n manifestasie van 'n Gattung is nie. "Daraus erhellt, dassman erst dann von einer Gattung sprechen kann, wenn man wenigstens zwei literarisch unabhängige gleich oder verwandt strukturierte Einheiten nachgewiesen hat; erst danach ist es möglich, die Frage der Gattungbezeichnung zu erörtern" ${ }^{20}$ Dit beteken met ander woorde dat tekseenhede nie sjablone ten opsigte van mekaar hoef te wees, alvorens hulle as 'n bepaalde Gattung gegroepeer kan word nie. Hoe meer ooreenkomste nodig is om aan die vereistes van 'n Gattung te voldoen, hoe kleiner is die Gattung, en hoe minder, hoe groter word die Gattung. ${ }^{21}$ Dit bring mee dat die term Gattung vir klein sowel as uitgebreide eenhede gebruik kan word, soos dit inderdaad ook die geval by die tradisionele Formgeschichte was. Heinrich Zimmermann ${ }^{22}$ het byvoorbeeld die term Gattung as die oorkoepelende begrip beskou, en het daaronder, wat die Nuwe Testament betref, die Evangelie, die Acta, die Brief en die Apokalips verstaan. Kleinere eenhede soos die paradigma het hy Formen genoem, en dan het hy nog kort, vaste uitdrukkings onderskei en dit Formeln genoem. 'n Gattung hoef dus nie altyd 'n perikoop te wees nie. Literêre tipes bestaan dikwels slegs uit 'n vaste literêre konstruksie. In sulke gevalle sal die perikoopafgrensing en struktuuranalise, soos in die geval van grotere eenhede, nie nodig wees nie. Identifisering moet egter steeds met inagneming van die onderskeid tussen sinchronie en diachronie geskied. In navolging van J A Loader ${ }^{23}$ gebruik ek die term Gattung vir sowel groot 
as kleinere eenhede, en die term Makrogattung vir die wyere eenhede soos die evangelie, ensovoorts.

Waar die vorm van ' $n$ eenheid aan die hand van formele sintaktiese kategorieë (kola) vasgestel word, word die Gattung geidentifiseer deur die gemeenskaplike "strukturmerkmale" van die struktureel-verwante en literêr-onafhanklike vorme te bepaal, en deur sodoende die karakteristieke van die Gattung te beskryf. Dit is die rede waarom Richter die tradisionele werkwyse bevraagteken wat die aspek van Geschichtlichkeit as kriterium gebruik om Gattungen te isoleer. Die gemeenskaplike struktuureienskappe kan nie op grond van 'n diachroniese vergelyking raakgesien word nie. "Das mag zutreffen," maar vele gevalle bewys egter die teendeel. ${ }^{24}$ Die vergelyking van die vorme van afsonderlike eenhede is uit die aard van die saak nodig om Gattungen te identifiseer. Maar hier geld ook die beginsel dat diachronie op sinchronie volg, en nie omgekeerd nie. ${ }^{25}$

Richter onderskei derhalwe twee sinchroniese fasette in Gattungsforschung. Die eerste noem hy Gattungskritik waar struktureel-verwante vorme vergelyk, en Gattungen geïsoleer word. (Uit die aard van die saak is die reeks tekste wat vir die ondersoek ter sake is, eers afgegrens, en is die struktuur van elke eenheid afsonderlik geanaliseer.) Die tweede is die vraag na die Sitz im Leben van die Gattung, en daarmee saam die vraag na sy funksie. Maar voordat ons oorgaan tot die bespreking van hierdie faset in Gattungsforschung, eers ' $n$ woord oor my belangrikste metodologiese wysiging ten opsigte van Richter se benaderingswyse, naamlik die verhouding van vorm en inhoud by Gattungsforschung.

Richter wys versigtig daarop dat hy inhoud "voorlopig" nie as konstitutief tot Gattung wil reken nie. ${ }^{26}$ Inhoud kan slegs ten opsigte van 'n konkrete tekseenheid vasgestel word. En omdat Gattung vir hom ' $n$ teoretiese abstraksie is, ... "der erst mit seiner Funktion hinreichend umschrieben ist", ${ }^{27}$ kan die "Texttypus" van 'n Gattung slegs op die groepering van afsonderlike inhoude (ooreenkomstig die verskillende afsonderlike konkrete tekseenhede) dui. Die "singuläre" inhoud van 'n afsonderlike tekseenheid wat op grond van objektiewe sintaktiese reëls saam met ander tot ' $n$ tipiese groep gereken word, is daarom as "Gattungsmerkmal" onbruikbaar ... "weil man sonst soviele Gattungsuntergruppen wie singuläre Inhalte in einer Formengruppe annehmen muss. Das würde den Gattungsbegriff sinlos machen."

Richter se standpunt in dié verband is myns insiens in die lig van wat tradisioneel gedoen is, wel begryplik, hoewel beslis te reaksionêr van aard. By die tradisionele benadering is daar dikwels onkontroleerbare kriteria by Gattungsforschung aangelê. Dit is ' $n$ saak wat vanaf die tyd van Gunkel telkens navrae kom, ten spyte van Barth en Steck $^{28}$ se prysenswaardige bewering dat hulle as eksponente van die 
tradisionele benadering met Richter saamstem dat daar tussen die aspekte vorm en inhoud onderskei moet word, maar dat die "Aussage-gehalt" ook nie weer bepaal kan word sonder die vasstelling van die vorm nie. Om C H Dodd ${ }^{29}$ met betrekking tot die makarismeperikope in die evangelies as voorbeeld te neem: Volgens Dodd vertoon die makarismeperikoop in die Matteus- en Lukasevangelie verskillende vorme waarvan elkeen ' $n$ eie onderskeidende en krakteristieke literêre produk is. Dié is verwant aan verskillende bestaande komposisionele vorme en elkeen staan, ten spyte van hulle groot gemeenskaplikheid, op sy eie voet. Die inhoud van die vorm in die Lukas-perikoop (makarismes teenoor wee-uitroepe) verkondig ' $n$ ommekeer van toestande. Dodd noem hierdie verskynsel die peripeteia - 'n saak wat ook in ander perikope in die evangelies voorkom. Die inhoud van die Matteus-perikoop het weer'n etiese strekking. Hy gaan dus van die standpunt uit dat daar ' $n$ korrelasie tussen vorm en inhoud bestaan. Afgesien daarvan dat die vorm nie volgens vaste omlynde kriteria geïsoleer is nie, het Dodd tog enkele struktuurmerkende elemente uitgewys. Hoewel hy dus wel 'n aanvoeling vir struktuurontleding gehad het, het hy egter nie die identifikasie van Gattungen daarop gebou nie, maar op die ou end feitlik slegs op die inhoudelike gesigspunte. ${ }^{30}$ Dieselfde vind ons vroeër by Gunkel. Sy kategorie, die Klagelieder des Volkes word van die kategorie Danklieder des Volkes op grond van die inhoudsmoment "dank" en "klagte" onderskei, terwyl die vorme nie wesenlik as diagnostiese kriteria gedien het nie. ${ }^{31}$

Richter se standpunt kom daarop neer dat hy inhoud by alle aspekte van Gattungsforschung buite rekening wil laat. Dit is egter 'n aangeleentheid waar die paaie van ondersoekers wat ver met Richter sal saamloop, begin uiteen gaan (myne inkluis). ${ }^{32}$ Vorm en inhoud is nie twee entiteite wat toevallig saamgevoeg word nie, maar dit is eerder so dat vorm en inhoud ' $n$ eenheid vorm wat saam betekeniskonstituerend is. In die semantiese struktuuranalitiese tegniek wat in die Nuwe-Testamentiese Werkgemeenskap van Suid-Afrika aangewend word en waar die suiwer sintaktiese kolonanalise van die teks ingevul word met 'n semantiese analise gebaseer op die Nidamodel van dinamies-ekwivalente Bybelvertaling, ${ }^{33}$ word die term "oppervlaktestruktuur" identies gebruik met wat Richter vorm noem en die term "dieptestruktuur" met wat Richter inhoud noem. ${ }^{34}$ Met dit in gedagte, is dit duidelik waarom ek vorm en inhoud nie wil skei nie. In dié verband bly die opmerking van Barth en Steck ${ }^{35}$ waar: “Was ist Aufbauanalyse, eine Gattungsbestimmung, was ist gattungsgeschichtliche Arbeit, wenn man von der inhaltlich-topischen Prägung und der thematischen Direktion sprachlicher Äusserungen absehen und sich allein an formalisierbare Phänomene halten soll?" Klaus Berger $^{36}$ gaan selfs só ver, myns insiens ten onregte, om Richter as 
"inhalts-feindlich" te bestempel. Gattungsforschung mag hom nie tot die formele alleen beperk nie. Richter se gesigspunt bied egter wel die raamwerk vir verfyning van resultate.

Aan die hand van 'n skematiese skets wil ek vervolgens my standpunt in die verband verder uiteen sit. Die skets dien terselfdertyd as'n samevatting van die nuwere benadering tot Gattungsforschung wat ek in hierdie artikel aan die hand doen. Die skets is aan Makert ${ }^{37}$ ontleen, maar vir my doel aangepas.

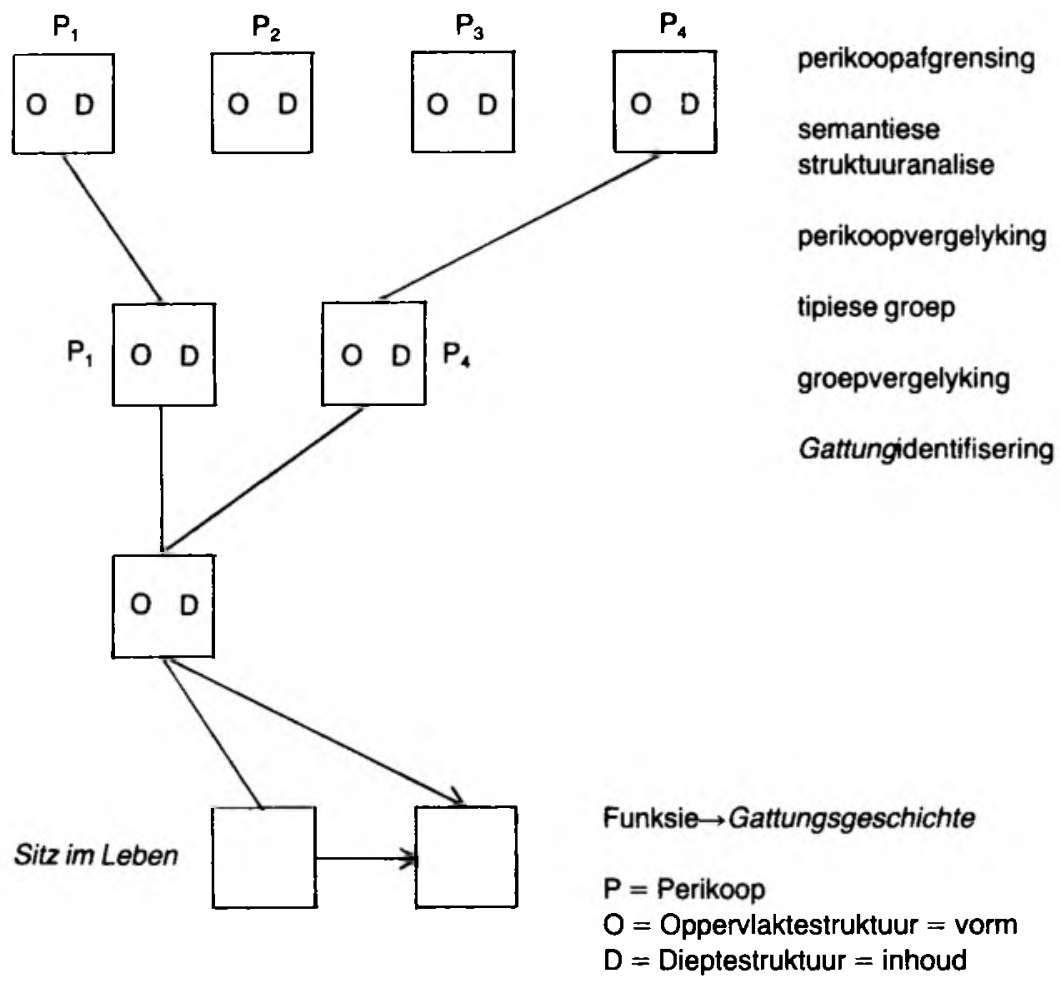

Uit bovermelde skets is dit duidelik dat die aspekte vorm en inhoud by al die metodiese fasette van Gattungsforschung in berekening gebring word. Nieteenstaande my simpatie vir Richter se standpunt, is ek van mening dat dit te eensydig is.

Daar bestaan in Richter se werkwyse 'n kontradiksie. Want by die perikoopafgrensing is 'n verskynsel soos "spanninge" (een van sy literarkritische kriteria) niks anders as ' $\mathrm{n}$ inhoudsmoment ${ }^{38}$ nie. Maar ook by die struktuuranalise kan inhoudsmomente 'n rol speel. Ek wil dit kwalifiseer aan die hand van 'n struktuuranalise wat J A Loader ten opsigte van Prediker 3:1-9 gemaak het. In dié fyn en kunstig gestruktureerde perikoop het Loader opgemerk dat die woord in een hemistige telkens die antitese is van die woorde in die een langs 


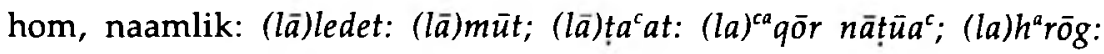
(li)rpō'; (li)prōṣ: (li)bnōt, ensovoorts, terwyl elke stigepaar weer op hulle beurt ' $n$ sinonieme parallelisme vorm. Loader maak in hierdie verband die opmerking: "Die belangrike waarneming wat ons hier gemaak het, is dat die bou of oppervlaktestruktuur van 'n perikoop ook met semantiese vrae te doen het. ${ }^{\prime \prime 3}$ Die riglyn wat myns insiens ten opsigte van hierdie kwessie moet geld, is dat die vorm van 'n tekseenheid primêr aan die hand van formele sintaktiese kategorieë bepaal word, en waar semantiese aspekte ' $n$ rol in dié verband kan speel, èn relevant kan wees, word die hulp van laasgenoemde ingeroep. Wat die identifisering van die Gattung betref, word die vergelyking van eenhede vereis wat nie net struktureel-verwant is nie, maar terselfdertyd ook betekenis-verwant is. Hier geld nie wat ons hierbo "inhoudsmomente" genoem het nie, maar inhoud in die sin van die betekenis van ' $n$ tekseenheid wat onlosmaaklik met sy vorm verbind is. Hierdie basiese, en belangrike uitgangspunt ten opsigte van die Gattungsforschung word in die bovermelde skematiese skets aan die hand van die simbole $O$ (oppervlaktestuktuur $=$ vorm) en $D$ (dieptestruktuur $=$ inhoud) verduidelik. Net soos die vorm en inhoud by ' $n$ semantiese struktuuranalise van 'n bepaalde tekseenheid te onderskeie is, maar hoegenaamd nie geskei kan word nie omdat dit saam betekeniskonstituerend is, net so kan die aspekte vorm en inhoud by die vergelyking van dié eenhede wat tot 'n tipiese groep gereken kan word, nie uitmekaar gehaal word nie. Die benaming van 'n bepaalde Gattung sal ten slotte 'n weerspieëling wees van die vorm-inhoudelike analise van die verskillende eenhede wat die Gattung ten grondslag lê.

Die wins van bostaande uiteensetting (wat grootliks met dié van Markert ooreenstem) is dat hier vir die eerste keer vaste omlynde kriteria geld waar diachronie (vergelyking van eenhede) op sinchronie (semantiese struktuuranalise) volg, en waar Gattungen nie slegs op inhoud (tradisionele Formgeschichte) gebaseer is nie, èn ook nie willekeurig eers op inhoud en dan op vorm nie. Só 'n willekeurigheid vind ons by die moderne benadering van Klaus Berger ${ }^{40}$ wat Gattungen, of anders gesê: "tekssoorte" wil bepaal op grond van die rolle wat die aktante by die mededeling van die teks speel. Volgens Berger, wat steun op die "neueren Rezeptionstheorie und Kommunikationstheorie", moet ons van dié standpunt uitgaan - juis omdat taal primêr tot doel het om te kommunikeer, dat alle "tekssoorte" kommunikasie-gerigte kenmerke vertoon en daarom volgens die tipe gespreksituasie onderskei moet word. Die onderskeiding is dus geleë in die rolle wat die spreker en die hoorder in die mededelingsaksie inneem. Die spreker byvoorbeeld kondig sy rol eksplisiet aan met die sogenaamde illokutiewe sinsoorte soos vraag, bewering, vermaning, ensovoorts en op grond hiervan kan verskillende "tekssoorte" 
onderskei word soos vrae, onderwysing, groet, vermaning, vertelling ensovoorts. Ander "tekssoorte" word weer bepaal op grond van die betrokke deelnemers, soos byvoorbeeld die gebed waar God en die mens as deelnemers optree, en ander weer op grond van die soort redetipe, byvoorbeeld ' $n$ dialoog of ' $n$ monoloog. Op só 'n wyse wil Berger syns insiens deeglik rekening hou met wat hy noem "eine multilinearen Betrachtungsweise der Gattungen". Berger toon egter dat hy nie met vaste kriteria werk nie. Sommige "tekssoorte" isoleer hy op grond van die inhoud. Sy definisie van wat Gattung is, vertoon groot gebreke, asook die benaminge wat hy aan sy onderskeie Gattungen gee. Die Emmausperikoop (Luk 24:13-35) noem hy "Wiedererkennungsgeschichte"; die episode wat voor Pilatus afspeel (Mark 15:1-5) word 'n "verhoor" genoem en Joh 1:1-18 'n "proloog". Hy toon dat hy nie veel begrip het vir die problematiek van Wolfgang Richter met betrekking tot die onderskeid tussen vorm en inhoud nie, en derhalwe ook nie vir die strukturele benadering van die nuwere taal- en literatuurwetenskap nie. Berger maak ook geen erns met die beginsel van die vergelyking van meerdere verwante tekste om Gattungen te isoleer nie.

\section{Die "sitz im leben" van die "Gattung"}

'n Eksegeet kan nie net die vorm en inhoud van 'n Gattung bestudeer nie; hy moet ook na die Sitz im Leben van die Gattung vra. Die Sitz im Leben is die resultaat van gewoontes wat in ' $n$ bepaalde tyd geheers het en wat so ' $n$ belangrike rol aan die sprekers en hoorders of skrywers en lesers toegeken het, dat besondere literêre tipes nodig geag is as uitdrukkingsmiddel wat vir ' $n$ bepaalde doel in daardie situasie dien ${ }^{41}$ So is daar byvoorbeeld in die wêreld van die Ou Testament en sy "Umwelt", die aktiwiteite van die kultus, wetlike instellings, gebruike en instellings van die koninklike hof, ensovoorts. Oorwinningsliedere is gesing by die terugkoms van die oorwinnaar, klaagliedere by 'n begrafnis, instruksies word deur die priester by die tempel afgekondig, ensovoorts. ${ }^{22}$ 'n Bepaalde "instelling" is dan ook gewoonlik die draer van meer as een Gattung. Wat onder andere die evangelies betref, is die tradisies oor Jesus eers mondeling oorgelewer voordat dit op skrif gestel is. Gedurende die mondelinge stadium het van hierdie tradisies sekere vorme aangeneem na gelang van die aard van die funksie wat dit in die vroeg-Christelike gemeenskap gehad het. " "Umfassend kann mann für die neutestamentliche Literatur die Verkündigung der Frohbotschaft, die christlichen Gottesdienst und die christliche Glaubensunterweisung als den Sitz im Leben der Urkirche angeben" ${ }^{44}$ In die evangelies moet dus onderskeid gemaak word tussen die Sitz im Leben der alten Kirche en die Sitz im Leben Jesu. ${ }^{45}$ 
Oor die herkenbaarheid van die Sitz im Leben huldig Richter myns insiens ook 'n te rigoristiese standpunt. Hy maak daarop aanspraak dat sy standpunt ' $n$ korrektief is op die tradisionele benadering in dié verband. Vanaf die tyd van Gunkel (met die vanselfsprekende verfynende modifikasie wat deur die jare aangebring is) is die beskrywing van die Sitz im Leben van 'n Gattung op grond van tweërlei uitgangspunte bepaal, naamlik uitgaande van die literêre vorm self en tweedens uitgaande van die sosio-kulturele besonderhede. Eersgenoemde word gelei deur vrae soos: Wie is die skrywer? Wie is die lesers? Wat die tweede betref, is, ten opsigte van $\mathrm{Ou}$ Testamentiese tekste, kennis van Israel en dan ook van die Oudoosterse huishouding, sosiaal-kultiese en godsdiensgeskiedenis noodsaaklik. ${ }^{46}$ Volgens Richter het die tradisionele Formgeschichte kriteria in die verband aangelê wat gebaseer is op "sachfremden Daten". Hy wil nie op sodanige buitetekstuele gegewens steun nie, ... "sondern aus der Literatur selbst, was durch Erkenntnis ihrer Strukturregeln und ihrer Intentionalität geschieht". ${ }^{77}$ Richter is hier myns insiens onnodig bang vir die gevaar van "diachronisme" waarteen James Barr ${ }^{48}$ reeds in die sestigerjare begin waarsku het. Richter moet daarom wel gelyk gegee word dat die belang van sinchroniese analise nie genoeg by herhaling beklemtoon kan word nie. Dit geld ook wat die beskrywing van die Sitz im Leben van 'n Gattung betref. Laasgenoemde is egter 'n aangeleentheid waar diachroniese oorwegings 'n rol móét speel. Vrae na die skrywer, lesers en sosio-kulturele besonderhede is noodsaaklik om die geordende lewenssituasie raak te sien waarna die struktuur en inhoud van 'n betrokke Gattung wys. Diachroniese oorwegings moet dus altyd weer deur die sinchroniese gekontroleer word. Die sinchroniese ondersoek bied die raamwerk en beskerming teen 'n willekeurige verval in "diachronisme". ${ }^{49}$

\section{Die funksie van die "Gattung"}

Richter maak die opmerking: "Die Gattung ist also ein operationaler Begriff, der erst mit seiner Funktionhinreichend umschrieben ist" ${ }^{50}$ Wat is die "funksie" van die Gattung? Die vraag na die "funksie" van die Gattung is, soos Markert dit uitdruk, die vraag na die verhouding tussen die Sitz in der Literatur van 'n konkrete tekseenheid wat 'n manifestasie is van ' $n$ bepaalde Gattung, en die tipiese Sitz im Leben van dié betrokke Gattung. ${ }^{51}$ Hierdie uiters belangrike onderskeid tussen die Sitz in der Literatur en die Sitz im Leben van 'n Gattung is 'n konsekwensie van Ferdinand de Saussure (hoewel Richter en die eksponente van die nuwere benaderingswyse dit nie eksplisiet só vermeld nie) se onderskeid tussen la langue en la parole. De Saussure het nuwe perspektiewe geopen met sy stelling dat die verskynsel taal (= le langage) op 'n sosiale en individuele vlak tot uiting kom. Op 'n 
sosiale vlak is dit 'n sisteem van tekens wat 'n bepaalde gemeenskap aanwend om met bepaalde klankvorme kommunikasie te bewerkstellig. Dit word aangedui met die tegniese term la langue (= ' $n$ taal). Die uiting op individuele vlak is eintlik die werklike aanwending van ' $n$ taal, naamlik taalgebruik. Laasgenoemde word aangedui met die term la parole. Dit is die werklike taalaktiwiteit op ' $n$ bepaalde moment deur'n bepaalde persoon. ${ }^{52}$ Net soos die term Gattung, is die term Sitz im Leben 'n operasioneel-hipotetiese kategorie wat te doen het met die verskynsel ' $n$ taal (la langue). Eers by die aanwending van die betrokke Gattung op individuele vlak in aktuele taalgebruik (la parole), kom die vraag na die Sitz in der Literatur aan die orde. Dit is in die lig hiervan dat Market se bydrae ten opsigte van sy gebruik van die term Sitz in der Literatur reliëf verkry. Die verdienste van die nuwere benadering in dié verband is dat daar hiermee in Gattungsforschung weggedoen word met die tradisionele opvatting van Gattung as 'n buite-literêre grootheid.

Soos reeds vermeld, is die vraag na die "funksie" van die Gattung die vraag na die verhouding tussen die Sitz im Leben en die Sitz in der Literatur van die bepaalde Gattung. H W Hoffmann ${ }^{53}$ stel dieselfde vraag op 'n ander manier: Is die Gattung "funktionstypisch" gebruik (dit wil sê ooreenkomstig die tipiese Sitz im Leben van die betrokke Gattung), of is die Gattung "funktionsatypisch" gebruik? Hoffmann (en so ook Markert) maak ter verduideliking hiervan van Amos 5:1-3 gebruik:

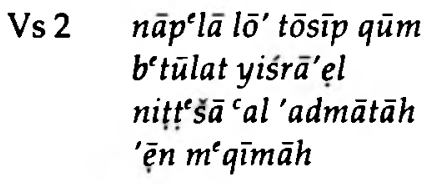

Amos 5:2 is 'n manifestasie van die Gattung "lyksrede" wat sy tipiese Sitz im Leben het by die begrafnis van'n mens. Weliswaar het dit hier op die ondergang van 'n volk betrekking. Die dood van 'n mens en die ondergang van 'n volk dui egter gemeenskaplik op dieselfde, soos die referensie $b^{c} t \bar{u} l \bar{a}$ inderdaad hier ook aantoon. In dié sin kan daar dus volgens Hoffmann se terminologie van 'n "funkstionstypische" gebruik van die Gattung gepraat word, omdat ons nie 'n verandering van Sitz im Leben het nie, maar wel 'n veralgemening. As die konteks egter in ag geneem word, asook die feit dat dit Amos se woorde is, dan verander die prentjie heeltemal. Israel was in die tyd van Amos nie op die punt van ondergang nie, maar van politieke hoogbloei. Met dit in ag genome, is die Gattung van die "lyksrede" hier dus eintlik "funktionsatypisch" gebruik. Die vraag na die "funksie" van die Gattung is daarom dus hier: Waarom het Amos die bepaalde Gattung van die "lyksrede" hier doelmatig, dit wil sê funksioneel vir die konteks geag? 


\section{Die "gattungsgeschichte"}

'n Verdere verdienste van die nuwe benadering is dat die laaste faset, die gattungsgeschichtliche, 'n aangeleentheid is wat logies uit die voorafgaande, die vraag na die "funksie" van die Gattung, voortvloei. Die gattungsgeschichtliche vraag is in sy geheel 'n diachroniese aangeleentheid. Die besondere metodiese plek wat hierdie faset in die nuwere benadering inneem, moet verstaan word in die lig van die noodsaklike onderskeiding tussen die sinchroniese en diachroniese metodiese fasette, die waarskuwing teen die vermenging van hierdie twee fasette en die feit dat sinchroniek diachronie vooraf gaan.

In wese verskil Richter nie met die tradisionele Formgeschichte oor die "wat" van Gattungsgeschichte nie. Gunkel het reeds opgemerk dat wanneer literêre tipes ontstaan, hulle in die loop van hulle gebruik kan ontwikkel, en daarom kan verander, of met ander kan vermeng en selfs nuwes kan vorm, of ten slotte kan verdwyn. ${ }^{55}$ Net soos G M Tucker, ${ }^{56}$ ' $n$ eksponent van die tradisionele benadering, wys Richter daarop dat die Sitz im Leben nie 'n historiese grootheid is in die sin dat daar vir elke Sitz im Leben 'n noue vaslegbare historiese datum gestel kan word nie. Dit is eerder só dat die Sitz im Leben aan 'n bepaalde historiese tydvak gebonde is. Dit is besonderlik die geval wanneer aan een of ander "instelling", soos byvoorbeeld die monargie, die Sitz im Leben uitmaak. Om die voorbeeld van die monargie verder te voer: Dit het sy wortels by die nāgid, sy begin by Saul, sy eiesoortige karakter onder Dawid en Salomo, sy selfstandige realisering in die Noord- en Suidryk, en ten slotte sy ondergang by beide ryke. En só kan daar ook ten opsigte van byvoorbeeld die profetedom dwarssnitte gemaak word. Elke sodanige snit omgrens ' $n$ bepaalde periode. Hieruit kan afgelei word dat die aktuele manifestasie van 'n Gattung slegs op 'n bepaalde Sitz im Leben betrekking kan hê en dat daarin die loop van die Sitze im Leben verandering by 'n Gattung kan intree. Dit kan dus gebeur dat 'n bepaalde Gattung buite sy oorspronklike Sitz im Leben gebruik word soos die voorbeeld van die monargie hierbo illustreer. Al het die oorspronklike Sitz im Leben verdwyn, kan 'n Gattung wat ooreenkomstig daarmee ontstaan het, dus voortbestaan. Dit kan egter ook gebeur dat 'n Sitz im Leben in só 'n mate ontwikkel dat nuwe Gattungen benodig word. Afgesien van totale nuwe Gattungen, kan 'n bepaalde Gattung in só 'n geval ook elemente van 'n ander Gattung (= Gliedgattung) uit 'n ander Sitz im Leben oorneem. In hierdie geval staan die nuut gevormde Gattung bekend met wat Gunkel 'n Rahmengattung genoem het. ' $n$ Bepaalde Gattung kan ook 'n volledige Gattung uit ' $n$ ander Sitz im Leben oorneem. Só 'n nuut gevormde Gattung staan bekend met wat Gunkel 'n Gattungsmischung genoem het. Hierdie ontwikkeling in die Gattung 
beteken dus in wese die vorming van 'n nuwe Gattung, omdat daar nie meer van presies dieselfde Gattung sprake kan wees nie. ${ }^{57}$ 'n Studie na hierdie en soortgelyke verskynsels staan bekend as die gattungsgeschichtliche ondersoek. Dit word gedoen deur'n bepaalde Gattung met ander eksemplare van soortgelyke literêre tipes te vergelyk. Enkele modifikasies wat eenmalig deur die skrywer aangebring is, is hier nie ter sake nie, behalwe as sulke modifikasies ook gattungsgeschichtlich werksaam word. In die nuwere benadering word sulke gattungsgeschichtliche verskynsels in verband met die vraag na die "funksie" van die Gattung gebring. ${ }^{58}$ Eintlik is dit eerder so, soos vroeër vermeld is, dat die gattungsgeschichtliche vraag uit die voorafgaande vraag na die "funksie" van die Gattung voortvloei.

Hierdie hele gattungsgeschichtliche aangeleentheid hou ook verband met die problematiek van die mondelinge oorlewering wat tot vandag toe baie aandag in die tradisionele formgeschichtliche ondersoeke veral ten opsigte van die Pentateug- en evangelienavorsing kry. Klaus Koch wil dan naas die gattungsgeschichtliche ondersoek ook nog 'n verdere twee aspekte as deel van Gattungsforschung reken, te wete die Überlieferungsgeschichte en die Redaktionsgeschichte. Barth, Steck en Markert is myns insiens oortuigend in hulle opvattinge om nie dieselfde mening te huldig nie. ${ }^{59}$ Dit is twee metodefasette wat elk ' $n$ afsonderlike behandeling verdien, ${ }^{60}$ hoewel aspekte van die gattungsgeschichtliche vraag raakpunte daarmee kan hê.

\section{Slotwoord}

My voorkeur om vir die term Gattungsforschung te kies as aanduiding vir die ondersoek na literêre tipes in Bybelse literatuur, behoef myns insiens in die lig van die terminologiese beperkthede, swakhede en verwarring van terme soos Formgeschichte, Formkritik, Formenkritik, Gattungskritik en Gattungsgeschichte, soos dit in die loop van die artikel geblyk het, nie 'n verdere betoog nie.

\section{VERWYSINGS}

'n Artikel gebaseer op 'n gedeelte van die skrywer se M A-verhandeling, Die "Betekenis" van die Makarisme reeks in Matteus 5 - Semantiek en "Gattungsforschung", Universiteit van Pretoria 1978.

$1 \mathrm{H}$ Gunkel e a, Die Schriften des Alten Testaments in Auswahl übersetzt und erklärt ${ }^{2}$ II 2, aangehaal deur K Koch, Was ist Formgeschichte? Neue Wege der Bibelexegese, Neukirchen-Vluyn ${ }^{3}$ 1974, 13.

2 W Richter, Exegese als Literaturwissenschaft, Entwurf einer alttestamentlichen Literaturtheorie und Metholodologie, Göttingen 1971, en veral die hoofstuk Die Gattung, 125-152. Sien ook sy artikel "Formgeschichte und Sprachwissenschaft", in ZAW, 82 (1970), 216-224.

3 G Wanke, "Sprachliche Analyse", in G Fohrer e a, Exegese des Alten Testaments. Einführung in die Methodik, Heidelberg 1973, 81. Wat Gattungsforschung spesifiek 
betref, kyk veral die artikel van L Markert in dieselfde boek, "Formen- und Gattungskritik", 81-99. Sien verder o a ook H W Hoffmann, "Form-Funktion-Intention" in ZAW 82 (1970), 341-346 en Jorgen Bjorndalen, "Form und Inhalt des motivierenden Mahnspruches" in ZAW 82 (1970), 347-361.

4 Sien o a Loader se Aspekte van menslike mag in die Ou Testament, Diss. Groningen 1975; asook sy "Gedagtes oor gekontroleerde eksegese", in HTS 34 (1978), 1-40. W S Prinsloo het ook in 'n onlangse artikel waardering vir hierdie benadering getoon, "Die Metodiek van Eksegese: 'n Diskussie", in NGTT 3 (1979), 201-210.

$5 \mathrm{~K}$ Berger, Exegese des Neuen Testaments. Neue Wegen vom Text zur Auslegung, Heidelberg 1977.

$6 \mathrm{~K}$ Koch, Was ist Formgeschichte? Neue Wege der Bibelexegese. Sien die appendiks "Nachwort: Linguistik und Formgeschichte", 298-342. Kyk ook sy "Reichen die formgeschichtliche Methoden für die Gegenwartsaufgaben der Bibelwissenschaft zu?" in ThLZ 11/98 (1973), 814 vv. In lg artikel (bl 804-807) tree Koch ook in diskussie met E Güttgemanns wat in sy boek Offene Fragen zur Formgeschichte des Evangeliums, München 1970, 'n eiendomlike strukturale benadering ten opsigte van die tradisionele Formgeschichte huldig.

$7 \mathrm{H}$ Barth en $\mathrm{O} \mathrm{H}$ Steck, Exegese des Alten Testament. Leitfaden der Methodik, Neukirchen-Vluyn ${ }^{4}$ 1973. Sien die appendiks "Nachtrag II: Zusammenfassende Stellungnahme zu W Richter's Methodenlehre 'Exegese als Literaturwissenschaft'," 104108.

8 W Richter, "Formgeschichte und Sprachwissenschaft", 219.

9 W Richter, Exegeseals Literaturwissenschaft, 126.

10 F de Saussure, Cours de Linguistique Générale, Parys 1916 . Vgl, veral onder die veeltal publikasies wat o a hierdiedrie linguistiese beginsels bespreek, A C Thiselton, "Semantics and New Testament Interpretation", in I H Marshall (red.), New Testament Interpretation. Essays in Principles and Methods, Exeter 1977, 79-85, 88-89.

11 W Richter, "Formgeschichte und Sprachwissenschaft", 216.

12 W Richter, Exegese als Literaturwissenschaft, $80 \mathrm{vv}$.

13 W Richter, "Formgeschichte und Sprachwissenschaft", 22-3; asook sy Exegese als Literaturwissenschaft, 50-62; $80 \mathrm{vv}$.

$14 \mathrm{Vgl}$ o a E Sellin (neubearbeitet: G Fohrer), Einleitung in das Alte Testament, Hedelberg $^{11} 1969,30$,.

15 Vglo a W A Beardsly, Literary Criticism of the New Testament, Philadelphia 1975.

16 Vgl veral J P Louw, Semantiek van Nuwe Testamentiese Grieks, Pretoria 1976, 75-99; asook sy "Discourse Analysis and the Greek New Testament", in BTr 24 (1973), 101118. Sien o a ook H C du Toit, "What is a Colon?" in Addendum to Neotestamentica 11 (1977), 1-10.

17 Vir die toepassing hiervan, sien A G van Aarde, Die "Betekenis" van die Makarismereeks in Matteus 5, en veral die hoofstuk "Die Struktuur van Mt 5:2-10 (en vs 11-16)", 68-70.

18 W Richter, Exegese als Literaturwissenschaft, 132 en L Markert, "Formen- und Gattungskritik", 82.

19 W Richter, Exegese als Literaturwissenschaft, 131. Hierdie onderskeid tussen vorm en Gattung word reeds beredeneerd gevind by D Greenwood, "Rhetorical Criticism and Formgeschichte: Some Methodological Considerations", in JBL 89 (1970), 420.

20 W Richter, Exegese als Literaturwissenschaft, 138. (My kursivering.)

21 L Markert, "Formen- und Gattungskritik", 99.

22 H Zimmermann, Neutestamentlichen Methodenlehre. Darstellung der Historisch-Kritischen Methode, Stuttgart ${ }^{4} 1974,135$ vv.

23 Menslike mag in die Ou Testament, 19.

24 W Richter, Exegese als Literaturwissenschaft, 129.

25 W Richter, a $w, 131$.

26 W Richter, $a w, 136 \mathrm{vv}$.

27 W Richter, $a w, 133$.

$28 \mathrm{H}$ Barth en $\mathrm{O}$ H Steck, Exegesedes Alten Testaments. Sien die appendiks "Nachtrage der 2. Auflage", 99.

29 C H Dodd, "The Beatitudes: a form-critical study", in More New Testament Studies, Manchester 1968, 1-10. 
30 Hoewel ons in die Lukas-perikoop (makarismes teenoor wee-uitroepe), in die terme van gunkel, met 'n Gattungsmischung te doen het, toon 'n ondersoek na die makarismeperikope in die Matteus- en Lukasevangelie vanuit die nuwe benadering dat beide perikope wel tot 'n tipese groep gereken kan word en derhalwe een en dieselfde Gattung manifesteer. In beide perikope is die Gliedgattung "makarisme" as 'n vormelement in die Rahmengattung "makarismereeks" aangewend. Vgl A $\mathrm{G}$ van Aarde, Die "Betekenis" van die Makarismereeks in Matteus5, 124 vv. 'n Artikel oor die makarisme as Gattung word in die vooruitsig gestel.

$31 \mathrm{H}$ Gunkel, Einleitung in die Psalmen. Die Gattungen der religiösen Lyrik Israels, Göttingen 1933, $\$ 4$.

32 Vgl in dié verband veral L Markert, "Formen- und Gattungskritik", 98 vv. H Barth en O H Steck, Exegese des Alten Testaments, 99 vv, oefen ook in dié verband skerp kritiek op Richter uit, maar toon dat hulle anders as Markert, nie insig het in die bydrae wat die moderne linguistiek op die gebied van Gattungsforschung kan lewer nie.

$33 \mathrm{Vgl}$ o a J P Louw, Semantiek van die Nuwe Testamentiese Grieks; E A Nida en C R Taber, The Theory and Practice of Translation, Leiden 1974; W S Vorster, "Moderne eksegese van die Nuwe Testament - 'n ondermyning van Skrifgesag?", in HTS 35 (1979), $120 \mathrm{vv}$.

34 Wanneer E A Nida en J P Louw die terme "oppervlaktestruktuur" en "dieptestruktuur" gebruik, bedoel hulle met hierdie terme nie dieselfde as byvoorbeeld $N$ Chomsky in sy publikasies vanaf Syntactic Structures, Den Haag 1957, nie. By Chomsky gaan dit om taalbeskrywing in sy sg Transformasioneel-Generatiewe Grammatika-model. Louw en Nida werk met die semantiese kategorieë objekte, gebeure en abstrakte by die ontleding van die dieptestruktuur en met sintaktiese "kernel sentences" by die ontleding van die oppervlaktestruktuur.

$35 \mathrm{H}$ Barth en $\mathrm{O}$ H Steck, Exegese des Alten Testaments, 100.

36 K Berger, Exegese des Neuen Testaments, 134.

37 L Markert, "Formen- und Gattungskritik", 98.

38 Met die term "inhoudsmoment" bedoel ek nie inhoud in die sin van die betekenis wat op grond van 'n semantiese struktuuranalise (ontleding van diepte- en oppervlaktestruktuur) vasgestel is nie, maar slegs die raamwerk waarin sodanige betekenis funksioneer. Vgl J A Loader, "Gekontroleerde eksegese", 9.

39 J A Loader, "Gekontroleerde eksegese”, 32. Vgl ook sy “Qohelet 3:2-8 - A 'Sonnet' in the Old Testament", in ZAW 81 (1969), 240-242.

$40 \mathrm{~K}$ Berger, Exegese des Neuen Testaments, $128 \mathrm{vv}$.

$41 \mathrm{~K}$ Koch, Was ist Formgeschichte?, 35-43. Vgl. ook J Annandale, "Wat is 'Formgeschichte'?", 'n artikel gebaseer op die boek van Koch, Th Evang 4 (1971), 18 vv.

$42 \mathrm{Vgl} \mathrm{J}$ Muilenburg, "The Gains of Form Criticism in Old Testament Studies", in Exp T $71(1959 / 60), 229$.

$43 \mathrm{Vgl} \mathrm{S} H$ Travis, "Form Criticism", in I H Marshall (red.), New Testament Interpretation, 154. (My kursivering.)

44 H Zimmermann, Neutestamentliche Methodenlehre, 173.

45 Die onderskeid tussen die Sitz im Leben der alten Kirche en die Sitz im Leben Jesu hou verband met die hele kwessie van die ipsissima verba Jesu en die ipsissima vox Jesu wat weer betrekking het op die vraagstuk oor die "historiese Jesus". Vir 'n oorsig oor resente ontwikkelinge op dié gebied, sien o a G Aulén, Jesus in Contemporary Historical Research, Philadelphia 1976.

46 Die Oudisrealitiese lewenswyse was nou verbonde aan die instellings van die antieke wêreld. Hof en tempel, byvoorbeeld, het die daaglikse lewe van die Egiptenaar, Babiloniër en Assiriër net soos van die Israeliet bepaal. Vgl K Koch, Was ist Formgeschichte? 43 en J Annandale, "Wat is 'Formgeschichte'?", 22.

47 W Richter, Exegese als Literaturwissenschaft, 145.

$48 \mathrm{Vgl} O$ a sy The Semantics of Biblical Language, Londen 1961.

49 Dit is dan ook nie 'n verrassing nie dat L Markert, "Formen- und Gattungskritik", 94, voortbouend op die nuwere benadering soos deur Richter ontwerp, steeds in hierdie verband, sonder om eksplisiet daaroor te besin, van die tradisionele kriteria gebruik maak.

50 W Richter, Exegese als Literaturwissenschaft, 133. (My kursivering.) 
51 L Markert, "Formen- und Gattungskritik", 95.

52 Benewens die verwysings in nota 10 , sien o a verder in dié verband ook $E \mathrm{~V}$ McKnight, Meaning in Texts. The Historical Shaping of a Narrative Hermeneutics, Philadelphia 1978, 97 vv.

53 H W Hoffmann, "Form-Funktion-Intention", 344 vv.

54 Die term Gattungsgeschichte word hier nie identies met die term Formgeschichte gebruik nie, maar wel as 'n element van Gattungsforschung.

55 Vir ' $n$ samevatting van Gunkel se bydrae in ' $n$ afsonderlike publikasie, kyk Die israelitische Literatur (Herausg.), Darmstadt 1963.

56 G M Tucker, Form Criticism of the Old Testament, Philadelphia ${ }^{3}$ 1975, 116.

$57 \mathrm{Vgl} \mathrm{H}$ Barth en $\mathrm{O} \mathrm{H}$ Steck, Exegese des Alten Testament, 59 en 63.

$58 \mathrm{Vgl} \mathrm{L} \mathrm{Markert,} \mathrm{"Formen-} \mathrm{und} \mathrm{Gattungskritik",} 97$.

$59 \mathrm{H}$ Barth en O H Steck, Exegese des Alten Testament, 56; L Markert, "Formen- und Gattungskritik", 85. Markert maak in dié verband die onderskeid tussen "origina"rer" en "nachgeahmter" Gattungen. Eg moet meestal as 'n mondelingse gegewenheid opgeneem word, terwyl $\mathrm{lg}$ in die reël literêr vergestalt is. W Richter, Exegese als Literatur wissenschaft, 139, 143, 148, praat weer van "primärer" en "konstruierter" Gattungen. E Güttgemanns, Offene Fragen zur Formgeschichte des Evangeliums, bring hierdie kwessie met De Saussure se onderskeid tussen la langue en la parole in verband.

$60 \mathrm{Vgl} \mathrm{J} \mathrm{A} \mathrm{Loader,} \mathrm{"Gekontroleerde} \mathrm{eksegese",} 5$. 